\title{
The Effect of the Economic Downturn on College Athletes and Athletic Departments on Issues of Diversity and Inclusion
}

\author{
Richard Lapchick \\ University of Central Florida
}

\begin{abstract}
In this paper I review the current and potential future effect of the economic downturn on matters of diversity and inclusion. I discuss reasons for cautious optimism in minority and female hiring patterns - both in the areas of athletic leadership and coaching. But this progress is uneven and tenuous. Special attention, I argue, is needed for the growing academic performance gap between white and AfricanAmerican student athletes. Any economically-driven cuts in academic support and life skills education could exacerbate this problem. I conclude that the economic downturn, to date, does not appear to have had a major effect on diversity and inclusion. However, because periods of economic crisis typically have a greater negative impact on minorities than others, we need to carefully monitor athletic and academic programs from high school through college and continue to advocate for this "fragile ideal" of racial and gender equality.
\end{abstract}

Race remains a contentious issue in college sport, and is a focal point of controversies in two primary areas. The first and most prominent is hiring practices (Lapchick, December 2009), and the second is the persistent gap between the graduation rates of African-American and white student-athletes (Lapchick, 2002-2010).

The recession has hit all aspects of higher education in the United States. Some believed that sports would avoid a crisis because they are "independent" from the central administrations. But this independence applies only to a few of the wealthiest departments. The annual College Racial and Gender Report Card has consistently shown that of all sports entities colleges have the worst record for hiring people of color and women. This presentation looks at the long and short term effect of the recession on the hiring practices of our colleges and universities and on high school students from economically disadvantaged communities having opportunities to play school sports at a level of excellence that may qualify them for athletic scholarship. It will also discuss the actual and potential effects of the economy on NCAA programs that support diversity and inclusion in college athletics and at the NCAA itself. 


\section{Who Runs College Sport Today?}

Last month was probably the best month ever for the image of college sports and racial equity as a record number of football coaches of color were employed at Football Bowl Subdivision (FBS) schools. Most recently, Louisville announced the hiring of Florida defensive coordinator Charlie Strong, which meant that $11 \%$ of the head coaches were men of color in a sport where about half the athletes are black (Lapchick, December 9, 2009). But football is hardly the only sport where equity is lagging.

An analysis of the racial and ethnic composition of coaches, assistant coaches, athletic directors, associate ADs, university presidents, board chairs, and conference commissioners of the BCS schools does not provide a very encouraging diversity picture (Lapchick, December 2009; Lapchick and McMechan, November 17, 2009).

Whites dominate the head coaching ranks on men's teams. They hold $89 \%$ of all head coaching positions in Divisions I, II and III, respectively. AfricanAmericans held $7 \%, 5 \%$ and $4 \%$ of the men's head coaching positions in the three NCAA divisions, respectively. Amazingly, there are more women coaching men's teams in Division III than there are African-Americans coaching men's teams. It is close in Division II.

On the women's teams, whites held 88, 89 and $92 \%$ of all head coaching positions in Divisions I and II and 93\% of those positions in Division III. AfricanAmericans hold 7, 5, and 4\% of the women's head coaching positions in the three NCAA divisions, respectively (Lapchick, December 2009).

As with the head coaching positions, Division III is the least diverse for student-athletes. But the percentages of African-American student-athletes are sharply different than for coaches who look like them in Divisions I and II. In Division I, African-American male student-athletes make up 25\% of the total male student-athletes and 24\% in Division II. In Division I and II, African-American female student-athletes comprise 16 and $13 \%$ of the total female student-athletes, respectively. In Division III, $9 \%$ of the men and $5 \%$ of the women are AfricanAmerican (Lapchick, December 2009).

I think most people believe there are numerous African-American assistant coaches, waiting and ready to step up when the opportunity comes. However, whites still hold 77,79 , and $88 \%$ of the assistant coaching positions on the men's teams in the three divisions, and 79,81 , and $89 \%$ on the women's teams. AfricanAmericans held 18,14, and $8 \%$, respectively on the men's teams and 14, 9, and $6 \%$, respectively on the women's team (Lapchick, December 2009).

People of color are doing better in athletics director jobs at the 120 FBS schools. As of December 2009, there were 11 (9.2\%) African-American men (University at Buffalo, University of Central Florida, Eastern Michigan University, University of Georgia, New Mexico State University, The Ohio State University, University of Southern California, Syracuse University, U.S. Military Academy at West Point, Vanderbilt University, and University of Virginia); four (3.3\%) Latino men (University of California, Los Angeles, Florida International University, University of North Texas, and University of Wisconsin, Madison) and one $(0.8 \%)$ Native American man (Tulane University). There were no Asian men and no women of color (Lapchick, December 2009). 
There were five $(4.2 \%)$ white women (Arizona State University, University of California, Berkeley, University of Maryland, College Park, University of Nevada, Reno, and Western Michigan University) directing athletics departments in which football teams are housed (Lapchick, December 2009).

But the FBS schools are an anomaly. When examining all three divisions, African-Americans hold only 7, 4 and $2 \%$ of the athletics director jobs, respectively in Divisions I, II and III. As they do everywhere else, whites dominate the position, holding 90, 92, and 97\% in Divisions I, II and III, respectively. Latinos constitute only 2, 2, and zero percent of all ADs.

Women hold AD positions in 8, 13 and $27 \%$ of the Division I, II and III institutions, respectively (Lapchick, December 2009).

As with assistant coaches, many people also assume there are significant numbers of African-Americans waiting in the wings as associate athletic directors. However, that is far from the truth as whites again dominate with 89, 89, and $96 \%$ of the total associate AD positions in the three divisions, whereas AfricanAmericans only hold 7, 8, and 3\% of the positions; and only 2, 2 and $0.4 \%$ of the Associate ADs are Latino.

Women were associate and assistant ADs in 28, 49 and $50 \%$ of the Division I, II and III institutions, respectively (Lapchick, December 2009).

Faculty Athletics Representatives (FAR) are 92, 92 and 96\% white. In the Senior Woman's Administrator role, 84, 91 and $96 \%$ of the jobs are held by white women (Lapchick, December 2009).

University presidents hire ADs and appoint FARs, and of the 120 FBS presidents at the end of 2009, 93\% (111) are white and 78\% (94) are white men. African-Americans and Latinos each hold only $2.5 \%$ of the presidencies in the group! There is one Asian president. Sixteen percent (19) are white women while there was one African-American, Latina and Asian woman as president (Lapchick and McMechan, November 17, 2009).

Less than one percent of board chairs at American colleges and universities are African-American, excluding, of course, the Historically Black Colleges and Universities that have not been included in any of the data I've just presented.

Although African-Americans, Latinos, and Asians are underrepresented in the aforementioned categories, they are absent among Conference Commissioners, the major power brokers in college sport. All (100\%) of the 11 FBS conference commissioners are white men. Among these 11 men are those that head BCS Conferences and hold what are now considered to be among the most powerful and influential positions in college sport. When you look at all of Division I, excluding the Historically Black conferences, all 30 (100\%) of Division I conference commissioners were white. Three conferences were led by women as commissioners (Lapchick and McMechan, November 17, 2009).

\section{Is There Positive Change Happening Regarding Who Will Run College Sport Tomorrow?}

At the end of 2008, I called for a civil rights movement in college sport (Lapchick, December 8, 2008). NCAA President Myles Brand worked hard for racial equality. However, even as president, he didn't have access to the tools needed to bring 
about significant change. It is 2010 and in nearly every major position in college sport, no matter what division, whites hold about 90 percent and often more, of the jobs-in a year when we elected an African-American president!

At this point, we need the stake-holders to get bold with Title VII lawsuits. We need an Eddie Robinson rule for all top level positions including coaches. We need Congress to hold hearings. We need all student-athletes, regardless of race and ethnicity to speak out. The system is broken when it is so exclusive, and it's long overdue to be opened so there is hope of reaching full inclusion in the foreseeable future.

The sports that made progress between 2008 and the beginning of 2010 were men's and women's basketball and football. What were the seeds of change for those sports?

As the coaching carousel went in motion during early December 2008, there were three African-American coaches left in the FBS schools, the lowest number in 15 years. Jobs for African-American coaches were lost at Kansas State, Washington and Mississippi State. Late in the 2008 hiring process, African-American coaches were hired at New Mexico, New Mexico State and Eastern Michigan hardly making up for the losses in the Big 12, Pac 10 and SEC. Randy Shannon at Miami (FL) was the only BCS conference coach who remained.

When Charlie Strong was introduced as Louisville's new head coach, there had been a wave of change in college football. The hiring season was just underway and with slots still remaining to be filled, there were 11 African-American head coaches and a total of 13 coaches of color at the 120 FBS schools. That's four more than at any point in the history of college football. Most importantly, there are again coaches of color in the BCS conferences with Strong in the Big East, Mike London in the ACC at Virginia and a good chance that Turner Gill may be going to Kansas in the Big 12.

The pressures exerted by the Black Coaches and Administrators (BCA), the NCAA under the leadership of the late Myles Brand, The Institute for Diversity and Ethics in Sport (TIDES) at the University of Central Florida, and others had been escalated over the past year. With the BCA's support, I've repeatedly called for an Eddie Robinson Rule, named after the Grambling State legendary coach, to force colleges to include candidates of color in every hiring process. This year, the State of Oregon passed House Bill 3118 which adopted such a rule for all state colleges and universities. Early in December, Portland State hired Nigel Burton as their head coach. He became one of a handful of African-Americans in the Football Championship Subdivision (FCS). Now up to eight other states are considering such legislation. The BCA is also seriously looking at initiating Title VII civil rights law suits against schools - a strategy that still may be necessary.

The BCA Football Hiring Report Card has had an effect on who made up the search committees and who was interviewed at FBS schools. During the 2008 hiring cycle, the process appeared to be more open. Twenty-seven percent of search committees members for FBS open positions were people of color and 29\% of the 122 candidates interviewed for the FBS open positions were candidates of color. The result was that with nine having head coaching jobs, there were more coaches of color in the 2009 season than in any previous season. That's an improvement over the past, but nine of 120 was still a disproportionately small percentage when more than half of the scholarship student-athletes at FBS schools were AfricanAmerican (Harrison and Yee, December 2009). 
In addition to extra external pressure for change, two critical and influential things occurred. First, three coaches of color had very successful years, with Randy Shannon leading Miami (FL) to the Champs Sports Bowl, Ken Niumatalolo guiding Navy to the Texas Bowl, and Kevin Sumlin coaching Houston to the Bell Helicopter Armed Forces Bowl. This was the first time that three coaches of color played in FBS bowl games in one year. In addition, Mike London led Richmond to win the national championship in the FCS Division in 2008.

The second influential factor was that college football finally had a hugely successful African-American coach speaking out for more opportunities for coaches of color as head coaches. Ironically, it was a recently retired NFL coach that stepped up. Tony Dungy, who became the first African-American head coach to win the Super Bowl, has been outspoken on this issue in stops across the nation. Dungy isn't just asking for any jobs. His aim has been jobs in the top conferences: the ACC, SEC, Big East, Big Ten, Big 12 and PAC 10. For years I've said that football coaches need someone like basketball had with John Thompson, John Chaney and Nolan Richardson. They stood up for change in the 1980s and now we barely notice when African-American coaches are hired or fired in college basketball. Twenty-three percent of college basketball coaches were African-American in the 2008-09 season. Tony Dungy, so widely respected, has provided a voice that is difficult to ignore.

Perhaps there's also been an "Obama effect." Through much of 2009, Floyd Keith, Charlotte Westerhaus, the NCAA Vice-President for Diversity and Inclusion, and I pointed out that we have an African-American President at the same time that we had such a poor record in hiring football coaches. So in December 2009, when Willie Taggart, Larry Porter, London, and Strong were hired at Western Kentucky, Memphis, UVA, and Louisville, Floyd Keith said, "This is a proud moment for us" (Lapchick, December 8, 2009).

In my mind, these hires may indicate that college football is now on the road toward full inclusion for head coaches. Further support is found in the fact that Kentucky and Maryland have named Joker Phillips and James Franklin as "coaches in waiting." But we need to keep up the pressure so we don't shift into reverse. History making won't occur if we take our eyes off the road.

These positive events lead me to think back to 1997 when I first met Coach Eddie Robinson at what was the start of working with him on his autobiography. We talked about the fact that there were only eight African-American head coaches. We discussed how Coach Robinson, who was then the winningest football coach in college history, had never even been asked for an interview at a Division IA school (now FBS) (Lapchick, April 16, 1997). When I spoke at his funeral in 2007, I told the audience of 9,500 people that Coach passed at a time when sadly there were only five African-American head coaches. I promised his family and all those there, including Floyd Keith, that we would increase pressure for change. Now, only two years later, I'm confident that Coach Rob is smiling a relieved smile as he looks down and sees Coach Strong and 13 coaches of color at major universities. Coach Robinson helped pave the way so others could join the struggle that would enable Tony Dungy, Floyd Keith and others to become game-changers. Hopefully, December 2009 will be remembered as the time when college football made a major move toward full racial and ethnic inclusion. But we all know that there is more road to travel and more work to be done.

In men's basketball, as I said, there was success and outspoken leadership. In women's basketball, the BCA initiated the BCA Women's Basketball Hiring 
Report Card in 2007-08. Before the first Report Card, there were only eight AfricanAmerican head coaches of women's team at the FBS schools and the percentage was nearly as bad as football. Basketball Hall of Fame Coach Vivian Stringer raised her voice during these two years and it was amplified by the national media after the collision between radio host Don Imus and Stringer's Rutgers team which was in the Final Four. In the first reporting period, the number of African-American head coaches nearly doubled from eight to 15 .

In the second year of the Report Card (2008-09), 25 coaches of color including 21 African-American women, three African-American men, and one Latino, were among the women's basketball coaches at FBS institutions. It was one of the most dramatic turnarounds in the history of college sport—clearly a result of the BCA's insistence that the hiring process be made fair.

Under the microscope, 14 out of the 16 schools (88\%) earned an "A" final grade showing that universities were making a conscious effort to be more inclusive in their hiring processes. Schools that communicated with the BCA/MOIC about available candidates, had a diverse search committee, interviewed diverse candidates and took their time when making the final decision on a head coach earned a high grade. It was all about the process. (Lapchick, April 22, 2009)

The Women's Basketball Coaches Association's own study of all Division I coaches showed that nearly one of every five NCAA Division I women's basketball head coaches was African-American and that two-thirds of NCAA Division I women's basketball head coaches were female.

Before discussing the role of the NCAA, I have to offer a note of caution about what is a major concern for me. The Black Coaches and Administrators are struggling financially and they are a key force for change. They were early in their history and are once again under the leadership of Executive Director Floyd Keith. Even before the recession, the BCA had their financial underpinnings swept away when the NCAA eliminated the extra preseason games. One of them was a benefit for the BCA that raised close to half of their of their annual budget. They subsequently lost their basketball tournament and that was another blow. Now the economy is compounding their financial problems. Without a financially stable BCA to protect the interests of student-athletes, coaches and administrators of color, continued progress is in jeopardy. It is as simple as that.

Another very positive factor for change has been the programs funded by the NCAA with the cooperation of the BCA and the respective coaches associations to prepare potential coaches to move into head coaching positions. The funding comes from the NCAA's Office for Diversity and Inclusion which was initiated in 2005. Charlotte Westerhaus has been the Vice-President in that office since it was created.

In 2009, that office continued to offer the following programs which clearly are positive factors in the progressive hiring changes that have taken place.

A. The NCAA Football Coaches Academy was for individuals with three to eight years of college football coaching experience. The Expert Coaches Forum brings together individuals with more than eight years experience. In 2008, 28 coaches participated while 19 attended in 2009.

B. The Champions Forum links coaches with ADs who give insights into hiring processes and offer career advice. 
C. The Future Football Coaches Academy is for individuals who have recently completed college eligibility and desire to become coaches.

D. The NCAA Leadership Institute for Ethnic Minority Males and Females is for individuals seeking careers in all aspects of college sport.

Between 2005 and the hiring cycle of 2008, eight coaches of color have been hired in Division I FBS and FCS. What follows is a list of all of the coaches of color hired since 2005 in Division I FBS and FCS followed by a program they participated in if it applies.

- Ron Prince-Former Coach at Kansas State (Expert Football Coaches Forum)

- Norries Wilson Columbia (Expert Football Coaches Forum)

- Trent Miles-Indiana State (Expert Football Coaches Forum)

- Kevin Sumlin-University of Houston (Expert Football Coaches Forum)

- Mike London-Richmond (NCAA Football Coaches Academy)

- Randy Shannon-Miami

- Mario Cristobal-Florida International

- Ken Niumatalolo-Navy

As can be seen, five of the eight had participated.

Mike Locksley (New Mexico), Mike Haywood (Miami of Ohio), Ron English (Eastern Michigan), Dwayne Walker (New Mexico State) and Tom Williams (Yale) all were hired in 2009 after they had attended the Expert Football Coaches Forum.

Furthermore, 19 of the 70 people who have participated in the NCAA and BCA's Achieving Coaching Excellence program for potential minority basketball head coaches have become head coaches.

Clearly there is hope now that each of the key sports where hiring minorities was such a problem have turned the corner. Football and women's basketball have highly successful African-American coaches. Football and women's basketball have key outspoken advocates in Tony Dungy and Vivian Stringer. The BCA is holding both sports accountable with their hiring report cards. There is evidence that most top level hiring cycles include diverse search committees, diverse candidates, seek out resources for candidates in the BCA and the MOIC, and are not rushing through the cycle. The NCAA is funding key programs that seem to be preparing aspiring coaches in these sports.

All these factors seem immune to the economy and any downturn except the NCAA support. As of this writing, there is no evidence that the NCAA has cut back in these areas. We definitely need to continue funding these programs because they work and are successful.

\section{The Academic Gap Between African-American and White Student-Athletes}

One of the areas where funding cut backs could hurt progress toward inclusion is on the academic progress of student-athletes in general and student-athletes of color in particular. Athletics departments have been enhancing academic and 
life skill programs for student-athletes for many years. Not only has staff been hired, but external consultants and trainers have regularly been brought to individual campuses. Often these external groups are paid for by the NCAA and/or conference offices. I founded the National Consortium for Academics and Sport 25 years ago. It currently has three major training programs including diversity management training, sexual harassment and gender violence prevention training, and a leadership training program that teaches critical decision-making skills to student-athletes while challenging them to be responsible for their decisions and those of their teammates.

These developments have resulted in vastly improved academic success outcomes for student-athletes. However, with the issue of diversity and inclusion being my focus today, the gap between the success of white and African-American student-athletes is a concern and may grow if these programs are cut because of the economy.

According to the study Keeping Score When It Counts: Assessing the 2009-10 Bowl-bound College Football Teams-Academic Performance Improves but Race Still Matters, overall academic progress has continued while the gap between white and African-American football student-athletes increased slightly for the 68 Football Bowl Subdivision (FBS) schools (formerly known as Division I-A schools) playing in 2009-10 college football bowl games. (Lapchick, Moss, and Hoff, December 7, 2009). It is an annual study and is followed by similar studies of the teams selected each year for the men's and women's Division I NCAA Basketball Tournaments. In all of the studies, year after year, the gap between white and African-American student-athletes has been the most disturbing issue although the graduation rates for both continue to rise ${ }^{1}$.

In the 2009-10 year, 91\% (61 of the 67 schools), the same as in the 2008-09 report and up from $88 \%$ in the $2007-08$ report, had at least a $50 \%$ graduation rate for their football teams; approximately $90 \%$ of the teams received a score of more than 925 on the NCAA's Academic Progress Rate (APR) versus $88 \%$ in the 2008-09 report $^{2}$.

The NCAA created the APR in 2004 as part of an academic reform package designed to more accurately measure student-athlete's academic success as well as improve graduation rates at member institutions.

In spite of the good news, the study showed that the disturbing gap between white and African-American football student-athletes remains a major issue; 21 teams or $31 \%$ of the bowl-bound schools graduated less than half of their AfricanAmerican football student-athletes, while only two schools graduated less than half of their white football student-athletes.

The wide gap between white and African-American football student-athletes' graduation success rates grew in spite of the slight progress with overall graduation rates. Each year the most troubling information in the graduation success rate study is the disparity between the GSR of African-American and white football student-athletes. This year, the GSR for African-American football student-athletes is 59\%, which is identical to GSR in the 2008-09 report. The GSR for white football student-athletes went from $76 \%$ in $2008-09-77 \%$ this year. This resulted in a one percent increase in the gap (17-18\%). The overall football student-athlete GSR improved slightly from 65.3 to 65.7 percent. 
However, the report emphasized that African-American and white football players graduate at a higher rate than their male nonathletic peers in the student body. The graduation rate for African-American male students as a whole is only $38 \%$, in comparison with the $62 \%$ graduation rate for white male students-an unacceptable $24 \%$ gap.

Among the disturbing figures in the 2009-10 football study that further show an increase in the disparity between white and African-American football studentathletes are the following:

- 57 schools (up from 56 in 2008-09) or 85\% had graduation success rates of $66 \%$ or higher for white football student-athletes, which was more than 2.8 times the number of schools with equivalent graduation success rates for African-American football student-athletes (20 schools or 30\%).

- Seven schools (up from five schools in 2008-09) or 10\% graduated less than $40 \%$ of their African-American football student-athletes, while no school graduated less than $40 \%$ of their white football student-athletes.

- 14 schools (up from 12 schools in 2008-09) or 21\% had graduation success rates for African-American football student-athletes that were at least 30\% lower than their rates for white football student-athletes.

- 35 schools (up from 29 schools in 2008-09) or 52\% had graduation success rates for African-American football student-athletes that were at least $20 \%$ lower than their rates for white football student-athletes.

- Only Southern Miss (eight percent higher), Troy (seven percent higher), Connecticut (five percent higher) and Rutgers (four percent higher) had graduation success rates for African-American football student-athletes that exceeded their rates for white football student-athletes. That was down from five schools in the 2008-09 study.

- Five conferences distinguished themselves from all of the FBS conferences represented in the APR study. The Atlantic Coast Conference, Big Ten, and Pac 10 are all represented by two teams in the top 10 APR scores. The Atlantic Coast Conference and the Big 12 had all seven of their bowl-bound member institutions receive an APR score greater than 925. Conference USA also joined the category with all six of its bowl bound member institutions receiving an APR score greater than 925 (Lapchick, Lopresti, and Reshard, March $18,2009)$.

The results of the 2009-10 Football study were consistent with previous bowlbound studies as well as the annual studies of the teams in the men's and women's Division I Basketball Tournaments (Lapchick, Lopresti, and Reshard., March 18, 2009; Lapchick, Johnson, and Kamke, March 15, 2009).

Cuts in academic and life skills programs would obviously be harmful. In addition to research, I conducted interviews in December 2009 with Joe Crowley, the former President of the University of Nevada and former NCAA President, Dan Guerrero, Tom Brennan, Chris Monasch, and Don DiJulia, athletics director at UCLA, LaSalle University, St. John's University, and St. Joseph's, and Mark Gumble, Director of Academic Services for Student-athletes at the University of 
Central Florida (Lapchick, December 11-12, 2009). They helped me gain greater insight into the economic realities.

The entire discussion raises another issue. We are constantly focusing on graduation rates in football and basketball in college. I rarely read about graduation rates in baseball, hockey, golf or tennis where the number of African-American student-athletes is between one and six percent. In those sports there are no restrictions on when athletes can turn pro. The only sports that limit when an athlete can enter are the NFL and NBA. Why do we care so much about African-American athletes? Is it partly because the NFL and NBA do not want to run minor leagues and colleges more than fill the bill? Why do some seemingly care more about the academic lives of these African-American athletes and not about white athletes in other sports?

\section{The Effect of the Recession on Diversity and Inclusion Efforts in College Sport}

With all of the current information and the clear nature of the racial inequities in college sport, what are the likely long and short-term effects of the recession of the future of diversity and inclusion efforts in college sport?

We know that historically, racial and ethnic inequities have been exacerbated by economic downturns. We have seen that African-Americans and Latinos have been disproportionately affected by foreclosures, because they were steered toward subprime loans. Furthermore, the accumulated wealth of almost every American, including African-Americans and Latinos, has taken a substantial blow recently. That, in turn, will affect their ability to send their children to college. It is clear that income and wealth are highly correlated to having a college degree. With the huge impact on higher education, the recession resulted in lost jobs for faculty and administrators. The adage, "last hired, first fired" imposes poor potential for newly hired faculty and administrators as people with experience and tenure are likely to be kept. That could mean a disproportionate loss for people of color who had been relatively new to the institution, but crucial to overall progress toward racial and ethnic inclusion.

Those that I interviewed have not had to cut positions. At St. John's and LaSalle, positions were not filled when some left with a "soft freeze." Some positions were unfilled at Nevada. Joe Crowley said, "The state of Nevada has been particularly hard hit by the downturn, and public higher education has had to pay a stiff price for the resultant decreases in tax revenue. The university budget cuts have been onerous, more so for athletics than most other areas on campus."

Crowley added that, "Cary Groth, our AD, is emphatically committed to advancing the diversity and inclusion agenda. Indeed, she has done much to move us forward at Nevada, including the hiring of female coaches and administrators. African American hires have also been a major priority. Our program has been recognized nationally for its record not only in hiring but in Title IX commitments generally." He predicts the downtown will not affect diversity and inclusion at Nevada.

LaSalle's Brennan has not had to make cuts but uses a soft freeze. He candidly shared that," if we would have had to terminate people or reduce positions, we 
would have probably looked at most recent hires at least in administrative areas. Many of our more recent hires do include people of color and women." He was not sure how that may have played out at other schools that did reduce positions.

At St. John's, AD Chris Monasch told me, "We have not seen any effect on hiring or retention of anyone at this point. Our university has a hiring freeze where we need specific approval to hire. To date we have filled all positions."

But schools have made cuts. As reported in College Athletic Clips, Stanford cut 21 staff positions in the athletic department. Stanford has been affected by the decline in endowments. AD Bob Bowlsby reportedly cut $\$ 7$ million after its endowment dropped by more than $\$ 110$ million. A lot of athletics departments would like such a problem.

Some schools have cut sports teams. Washington cut men's and women's swimming while MIT dropped eight teams saving \$1.2 and \$1.5 million, respectively.

Several schools, including Michigan and Ohio State, stopped publishing media guides and recruiting brochures to save on printing and shipping costs. It fit well with going green.

William Kirwin, former Ohio State President and now chancellor of the University System of Maryland, has always been a critical observer of college sport. He said, "In a lot of ways, I see parallels between the implosion of our economy and the excessive spending in college athletics. There was an assumption that housing prices would always go up and up. You could buy a house and everybody assumed its value would increase. Intercollegiate athletics has lived in this fantasy world and assumed corporate sponsorships and TV contracts would always go up. Now we're finding out that's not the case."(College Athletic Clips, 2009)

The State of Louisiana cut $\$ 160$ million from higher education. Southern University dropped men's tennis and women's golf, Nicholls State cut women's golf and Southeastern Louisiana lostmen's tennis. Louisiana Tech, UL Monroe and Grambling-face cuts of \$21 million from their 2009-10 budgets and sports will absorb part of that. Grambling faces a nearly $\$ 5$ million dollar cut. I can be a witness that Grambling cannot afford that and athletics is sharing $28 \%$ of the cut. Their glory days, already fading, will be shelved until money can be found.

But then there is the State's BCS giant at LSU in Baton Rouge. It is one of the recipients of the SEC's riches and should be fine in a state of misery (McDonald, May 20, 2009). The SEC has a 15-year, \$3 billion TV deal which could give each school nearly $\$ 10$ million a year. ESPN will televise an average of an SEC game each day or more than 5,500 over the 15 years. There won't be many cuts with that size payout (Weiszer, June 28, 2009). Then there are media sponsorship packages. Georgia will get an additional \$92.8 million over eight years from ISP. While Georgia is the top revenue generator in this category, Ohio State $(\$ 110$ million for 10 years), Florida, Alabama, Texas and Nebraska (\$112.5 million for 13 years) all earn more than $\$ 8.5$ million a year (Sugiura, June 17, 2009). Hopefully they can use some of the resources to show others the way to inclusion.

"Tax Preferences for Collegiate Sports," a report from the Congressional Budget Office estimated that $60-80 \%$ of the revenue of BCS schools comes from commercial sources which FCS schools and non BCS FBS schools do not have as much access to making them much more vulnerable to a weak economy.

Smaller schools take games with BCS schools to build their budgets and may be more tempted in this economic climate. 
San Jose State moved a traditional game with Stanford to accommodate Alabama in 2010 with a million dollar payout. Many non BCS schools do that each year, sometimes with more than one game. The result is usually a blowout defeat and can leave their players battered. When UCF played at Texas in 2009, head coach George O'Leary did not play the starting quarterback or their number one running back, saying they were injured. He may have learned from Wyoming which lost two starters including their quarterback in a 53-3 loss at Texas A \& M (Gagliardi, June 21, 2009).

UCF's Mark Gumble told me the cuts he has seen were "more in the area of travel with buses instead of planes and regional rather than national competition, conference calls instead of meetings, facility upgrades vs. new construction." Monasch noted that "We have attempted to cutback in areas that we believe were elective in nature and do not have an impact on the experience of the student-athlete or our ability to compete." Brennan said, "There is no impact at La Salle on the academic /student welfare area. It is our most high priority. For me, it was off the table when reviewing possible reduction areas."

Some institutions are cutting scholarships. In athletics, this is especially true for non BCS schools. Coaches may be looking for ways to split the remaining scholarships. There was speculation that the budgets of academic support programs are likely to decrease with a particularly dire effect on athletes who are special admits and, therefore, may not get adequate assistance to allow them to compete academically with regular college students. If they do not graduate, they will be less employable themselves.

However, the people I interviewed, who came from various levels of Division I, believed that academic and social support for student-athletes would be protected. DiJulia, Brennan and Monasch said that support for student-athletes was untouchable.

However, at schools with smaller and shrinking budgets and where winning is not as critical as at the BCS institutions, coaches may look for recruits who will need little or no academic and social support as college students. This may, in turn, favor middle and upper-middle class young people whose families have the resources to help support the academic success of their children.

Where the economy reduces the number of students of color in general, African-American and Latino student-athletes may become more socially isolated on campus than they already are, thus causing them more serious adjustment problems.

Where jobs are cut, interns may be brought on but often without pay. Other regular internship programs that could assist athletes in need of job experiences might be reduced, at least temporarily.

\section{The Economy and High School Sports and Student-Athletes}

Then there is the effect of a significant percentage of student-athletes of color coming from urban high schools with poor resources, outdated technology, and faculty who are trying to stay in the game rather than ahead of it educationally as too many flee to the suburbs. Thus the relatively poorer academic preparation of the students in these schools will challenge them if they are admitted to institutions 
of higher education as student-athletes. They will need all the academic assistance and tutoring they can get to catch up to the other students. Any budget cuts in these areas could be fatal to their academic futures.

Many high schools will face losing sports programs if the economy does not come back soon. Without the varsity sports, fewer urban children will be able to get college scholarships and the added diversity that college sports often brings will affect the colleges' demographics.

Parents who fall deeper into debt may ask their children to work after school instead of playing sports, thus reducing the students and student-athletes chances of attending college.

If high school coaching staffs are cut, many African-American coaches with less seniority may lose their jobs first. That could be true in college as well.

\section{Conclusion}

With the terribly inequitable state of racial and gender hiring practices in college sport and the continuing disparities between the graduation rates of white and African-American student-athletes, we cannot afford any setbacks caused by the recession. While higher education in the United States is facing an economic crisis, it appears that there is currently a lesser impact on athletics departments in BCS schools where TV revenue and income from sponsorship deals can make up for cuts. Cuts are being dealt with in non-BCS FBS schools and in FCS schools but there are no reports of cuts in areas that would directly impact diversity and inclusion. But in both cases, deals had been signed and tickets sold before the recession, so these programs may be affected more severely if the downturn is prolonged, or they may experience delayed effects as families and students from certain racial and ethnic backgrounds face increasing barriers related to sport participation at the youth and high schools levels.

With the historic inequities endured by minorities in higher education, including college athletics, we must watch carefully for signs that the economy may negatively affect diversity in college sport. Right now hiring of people of color and women seems stable. So do the academic support systems at the college level. The NCAA has not announced cuts to affect its diversity and inclusion programs. A major concern is that the Black Coaches and Administrators are struggling financially and they are a key actor. I am committed to the report cards and other data collection and analysis that will provide regular assessments of diversity and inclusion. Without such data, people in leadership positions are bound to become complacent as they respond to constituencies more influential than underrepresented racial and ethnic minorities and women.

Right now we need to collect data and monitor what occurs in secondary schools and school districts. Opportunities for student-athletes in low income communities to play their sports and make it to the college level though an athletic scholarship could be at stake.

Racial equity is a fragile ideal. Despite the fact that we now have an AfricanAmerican President, racial and ethnic realities have not changed for most people. Expectations are high when realities can come crashing against the hope. The economy has stalled progress toward inclusion in many spheres of life in the United 
States. When the Civil Right and Voting Rights Acts were passed during the 1960s, many people thought we had come to that great moment when equality was finally inevitable. When it was not achieved, the riots in hundreds of cities assured us we needed more struggle, work and more vigilance. This lesson now can be applied to college sports: there has been progress on diversity and inclusion issues, but today, especially in the face of economic recession, there is a need for continued work and vigilance_-and struggle.

\section{Notes}

1. NCAA statistics were used in this study. The Institute reviewed data collected by the NCAA from member institutions for the graduation rate study. The Institute reviewed 2002-03 graduation (six-year) rates, with a four-class average (freshmen classes of 1999-00, 2000-01, 2001-02 and 2002-03).

2. The APR scores do not include data from the 2008-09 academic performances of the teams in the study but instead use four years of data ending in the 2007-08 school year.

\section{References}

College Athletics Clips. (2009). Universities - and athletics programs-are finding it harder and harder to balance their budgets. Retrieved December 15, 2009 at: http://www. collegeathleticsclips.com/index.php/archive/revenues/2502-news-flash-college-sportsare-not-recession-proof.

Gagliardi, R. (June 21, 2009.) Money games are a quick fix to ailing sports departments. Wyoming Tribune-Eagle. Retrieved December 15, 2009 at: http://findarticles.com/p/ news-articles/wyoming-tribune eagle/mi_8203/is_20090621/money-games-quick-fixailing/ai_n52135837/?tag=content;col1.

Harrison, K. and Yee, S. (December, 2009). The Sixth BCA Football Hiring Report Card 2008-09. Indianapolis, IN: Black Coaches and Administrators.

Lapchick, R., Johnson, W., \& Kamke, C. (March 15, 2009). Keeping Score When It Counts: Graduation Rates for 2009 NCAA Men's Division I Basketball Tournament Teams. Orlando, FL: The Institute for Diversity and Ethics in Sport (TIDES) at the University of Central Florida.

Lapchick, R., Lopresti, C., \& Reshard, N. (March 18, 2009). Keeping Score When It Counts: Graduation Rates for 2009 NCAA Women's Division I Basketball Tournament Teams. Orlando, FL: The Institute for Diversity and Ethics in Sport (TIDES) at the University of Central Florida.

Lapchick. R. (April 22, 2009). BCA Hiring Report Card for Women's College Basketball (2008-9). Black Coaches Association. Accessed April 29, 2009 at: http://bcasports. cstv.com/auto_pdf/p_hotos/s_chools/bca/genrel/auto_pdf/09-wbb-hiring-report-card.

Lapchick, R. and McMechan, D. (November 17, 2009) The Buck Stops Here: Assessing Diversity among Campus and Conference Leaders for Football Bowl Subdivision (FBS) Schools in the 2009-10 Academic Year. Orlando, FL: The Institute for Diversity and Ethics in Sport (TIDES) at the University of Central Florida.

Lapchick, R. (December, 2009). The 2008 College Racial and Gender Report Card. Orlando, FL: The Institute for Diversity and Ethics in Sport (TIDES) at the University of Central Florida.

Lapchick, R., Moss, A., \& Hoff, B. (December 7, 2009). Keeping Score When It Counts: Assessing the 2009-10 Bowl-bound College Football Teams - Academic Performance Improves but Race Still Matters. Orlando, FL: The Institute for Diversity and Ethics in Sport (TIDES) at the University of Central Florida. 
Lapchick, R. (December 8, 2009). Personal interview with Floyd Keith.

Lapchick, R. (December 9, 2009). A Historic Week for Minority Coaches. Special Report to ESPN.com. Accessed December 15, 2009 at: http://sports.espn.go.com/espn/ commentary/news/story?page=lapchick/091209.

Lapchick, R. (December 11 and 12, 2009). Personal interviews with Joe Crowley, the former President of the University of Nevada and former NCAA President; Dan Guerrero, Athletics Director at UCLA; Tom Brennan, Athletics Director at LaSalle University; Chris Monasch, Athletics Director at St. John's University; Don DiJulia, Athletics Director at St. Joseph's University; and Mark Gumble, Director of Academic Services for Student Athletes at the University of Central Florida.

Lapchick, R. (December 8, 2008) A call to civil rights action in college football. Special report to ESPN.com. Accessed December 18, 2009 at: http://sports.espn.go.com/ncf/ columns/story?columnist=lapchick_richard\&id=3755312.

Lapchick, R. (April 16, 1997). Personal interview with Eddie Robinson.

Lapchick, R. et al. (2002-2010). Graduation Rate Studies (Keeping Score When it Counts). Orlando, F.L. The Institute for Diversity and Ethics in Sport (TIDES) at the University of Central Florida. Available at: http://www.tidesport.org/ncaagraduationrates.html.

McDonald, D. (May 20, 2009). "Cuts run deep for college sports in Louisiana and beyond," posted on neworleans.com.

Sugiura, K. (June 17, 2009). UGA signs \$92.8 million media rights deal. Atlanta JournalConstitution. Accessed June 28, 2009 at: http://ajcmobile.com/uga/content/sports/uga/ stories/2009/06/17/uga_media_rights.html.

Tucker, T. (June 28, 2009). Georgia's athletics budget in good shape 'Good financial footing,' Atlanta Journal-Constitution. Accessed on December 19, 2009 at: http://www.ajc.com/ uga/content/sports/uga/stories/2009/06/28/georgia_athletics_budget.html.

Weiszer, M. (June 28, 2009). UGA deals media rights for big bucks. Athens Banner Herald. Accessed on December 15, 2009 at: http://www.onlineathens.com/stories/061809/ foo_451957110.shtml. 